\title{
Effect of Dietary Lead on Intestinal Nutrient Transporters mRNA Expression in Broiler Chickens
}

\author{
Roohollah Ebrahimi, ${ }^{1}$ Mohammad Faseleh Jahromi, ${ }^{1}$ Juan Boo Liang,, \\ Abdoreza Soleimani Farjam, ${ }^{1}$ Parisa Shokryazdan, ${ }^{2}$ and Zulkifli Idrus ${ }^{1}$ \\ ${ }^{1}$ Institute of Tropical Agriculture, Universiti Putra Malaysia, 43400 Serdang, Selangor, Malaysia \\ ${ }^{2}$ Faculty of Veterinary Medicine, Universiti Putra Malaysia, 43400 Serdang, Selangor, Malaysia \\ Correspondence should be addressed to Juan Boo Liang; jbliang@upm.edu.my
}

Received 25 August 2014; Revised 13 November 2014; Accepted 13 November 2014

Academic Editor: Kui Li

Copyright (C) 2015 Roohollah Ebrahimi et al. This is an open access article distributed under the Creative Commons Attribution License, which permits unrestricted use, distribution, and reproduction in any medium, provided the original work is properly cited.

\begin{abstract}
Lead- $(\mathrm{Pb}-)$ induced oxidative stress is known to suppress growth performance and feed efficiency in broiler chickens. In an attempt to describe the specific underlying mechanisms of such phenomenon we carried out the current study. Ninety-six oneday-old broiler chicks were randomly assigned to 2 dietary treatment groups of 6 pen replicates, namely, (i) basal diet containing no lead supplement (control) and (ii) basal diet containing $200 \mathrm{mg}$ lead acetate/kg of diet. Following 3 weeks of experimental period, jejunum samples were collected to examine the changes in gene expression of several nutrient transporters, antioxidant enzymes, and heat shock protein 70 (Hsp70) using quantitative real-time PCR. The results showed that addition of lead significantly decreased feed intake, body weight gain, and feed efficiency. Moreover, with the exception of GLUT5, the expression of all sugar, peptide, and amino acid transporters was significantly downregulated in the birds under $\mathrm{Pb}$ induced oxidative stress. Exposure to $\mathrm{Pb}$ also upregulated the antioxidant enzymes gene expression together with the downregulation of glutathione S-transferase and Hsp70. In conclusion, it appears that $\mathrm{Pb}$-induced oxidative stress adversely suppresses feed efficiency and growth performance in chicken and the possible underlying mechanism for such phenomenon is downregulation of major nutrient transporter genes in small intestine.
\end{abstract}

\section{Introduction}

Lead $(\mathrm{Pb})$ is one of the widespread environmental pollutants that induce a broad range of physiological and biochemical dysfunctions in animals [1]. Mahesar et al. [2] reported that most of the poultry feed samples which they analyzed contained greater amount of $\mathrm{Pb}$ and cadmium $(\mathrm{Cd})$ than the maximum tolerable levels for poultry. This observation suggests the possibility of accumulation of $\mathrm{Pb}$ in commercially produced poultry meat and meat products. Being a cumulative poison, $\mathrm{Pb}$ is also accumulated in various organs, such as brain, liver, kidney, bone, and hemopoietic system [3$5]$ and inhibits growth [6, 7]. Several researchers suggested that the biochemical and molecular mechanism of $\mathrm{Pb}$ toxicity involve the induction of oxidative stress in target cells and generation of reactive oxygen species (ROS), followed by DNA damage and apoptosis partly via the (1) direct effect of $\mathrm{Pb}$ on cell membranes, (2) $\mathrm{Pb}$-hemoglobin interactions,
(3) consistent reduction in blood delta-aminolevulinic acid dehydratase (ALAD), an erythrocyte enzyme sensitive to $\mathrm{Pb}$, and (4) effect of $\mathrm{Pb}$ on antioxidant defense systems of cells [813]. Low levels of intracellular ROS play a major role in redox signaling, but in high amounts ROS cause lipid peroxidation, compromise the cell membrane integrity, and deactivate the membrane-bound receptors and enzymes [14]. In addition, varying levels of ROS may impact mRNA and protein expression [15]. These changes are elicited primarily by transcriptional and posttranscriptional mechanisms via alterations in chromatin metabolism and transcription factors activity [16] and also RNA-binding proteins and microRNAs [17-19]. Evidently, Roche et al. [20] showed that increased production of ROS by gamma radiation in mice downregulates the mRNA abundance of intestinal sugar transporters. Nutrient transport is essential function of the small intestine and its disruption reduces nutrients utilization and feed efficiency. Regarding Pb-induced oxidative stress, except some reports 
on effects of $\mathrm{Pb}$ on loss of intestinal absorptive surface area $[21,22]$, there has not been a single study reporting on the alterations in mRNA expression of intestinal transporters. Earlier study of Damron et al. [21] demonstrated that feeding diet containing $1000 \mathrm{ppm} \mathrm{Pb}$ suppressed feed intake, body weight gain, and feed efficiency in chicken. The adverse effect of $\mathrm{Pb}$ on performance also has been reported for as low as $1 \mathrm{ppm}[23,24]$. Decreased intestinal epithelial cell proliferation and loss of absorptive surface area under stress condition have been shown to be the reason for such poor performance [25]. However, Nasir et al. [26], Garriga et al. [27], and $\mathrm{Hu}$ and Guo [28] showed that oxidative stress by corticosterone or heat exposure increased glucose absorption, which might not be explained by the decreased small intestinal surface area and likely to be associated with a change of nutrient transporter in the small intestinal epithelium during stress. Some studies confirmed this possibility, showing that starvation stress increased expression of sodium glucose cotransporter 1 and peptide transporter $1 \mathrm{mRNA}$ in the small intestine of chickens and rats [29-31].

To date, the actual mechanism by which ingestion of $\mathrm{Pb}$ suppresses body weight gain and feed efficiency remains unclear. We hypothesized that $\mathrm{Pb}$ affects mRNA expression of nutrient transporters across the intestinal wall and thereby reduces nutrients utilization. Therefore, the objective of this study was to determine the effects of $\mathrm{Pb}$-induced oxidative stress on mRNA expression of 4 sugar (monosaccharides) transporters: $\mathrm{Na}^{+}$-dependent glucose and galactose transporter (SGLT1), glucose transporter (SGLT4), $\mathrm{Na}^{+}$-independent glucose, galactose and fructose transporter (GLUT2), and $\mathrm{Na}^{+}$-independent fructose transporter (GLUT5). Two other nutrient transporter genes, namely, oligopeptide transporter (PepT1) and the excitatory amino acid transporter (EAAT3), and antioxidant enzymes were also studied.

\section{Materials and Methods}

2.1. Animals. Ninety-six one-day-old (Cobb500) male broiler chicks were obtained from a local hatchery and weighed and housed at 12 battery cages of 8 chicks each. Feed and water were provided ad libitum and lighting was continuous. Experimental procedure followed the ACUC (Animal Care and Use Committee) of Universiti Putra Malaysia.

2.2. Experimental Design and Procedure. Commencing from day one, 6-replicate cages were randomly assigned to either (i) basal diet containing no supplemented lead acetate (control) (Table 1) or (ii) basal diet supplemented with $200 \mathrm{mg}$ lead acetate/kg (Nacalai Tesque, Kyoto, Japan) [1, 32, 33]. The analyzed concentration of $\mathrm{Pb}$ in the control and lead supplemented diets was 0.155 (negligible) and $127 \mathrm{mg} / \mathrm{kg}$, respectively. Body weight and feed intake were recorded and feed efficiency was calculated for the 1-21-day period. Accordingly, daily ingestion of $\mathrm{Pb}$ was 6 and $5100 \mu \mathrm{g}$ in control and lead supplemented birds, respectively. Analysis of liver samples confirmed $\mathrm{Pb}$ retention in birds tissue ( 0.05 and $0.64 \mathrm{mg} / \mathrm{kg}$ in control and lead supplemented birds, resp.).
TABLE 1: Ingredient composition of basal diet.

\begin{tabular}{lc}
\hline Ingredient (g/kg unless otherwise stated) & $1-21$ days \\
\hline Ground yellow corn & 538.9 \\
Soybean meal & 361.9 \\
Fish meal & 30.0 \\
Palm oil & 37.4 \\
Choline chloride (60\%) & 2.5 \\
Trimix ${ }^{1}$ & 1.0 \\
Salt (NaCl) & 2.0 \\
DL-methionine & 1.8 \\
Limestone & 13.0 \\
Dicalcium phosphate & 11.5 \\
Total & $\mathbf{1 0 0 0 . 0}$ \\
Calculated analysis (g/kg except energy) & \\
Crude protein & 220.0 \\
Crude fat & 63.1 \\
Crude fiber & 38.0 \\
Calcium & 10.2 \\
Phosphorus & 4.5 \\
Metabolisable energy (MJ/kg) & 13.06 \\
\hline
\end{tabular}

${ }^{1}$ Trimix (per kg Trimix): iron $100 \mathrm{~g}$; manganese $110 \mathrm{~g}$; copper $20 \mathrm{~g}$; zinc $100 \mathrm{~g}$; iodine $2 \mathrm{~g}$; selenite $0.2 \mathrm{~g}$; cobalt $0.6 \mathrm{~g}$; santoquin $0.6 \mathrm{~g}$; folic acid $0.33 \mathrm{~g}$; thiamin $0.83 \mathrm{~g}$; pyridoxine $1.33 \mathrm{~g}$; biotin $2 \% 0.03 \mathrm{~g}$; riboflavin $2 \mathrm{~g}$; cyanocobalamin $0.03 \mathrm{~g}$; D-calcium pantothenate $3.75 \mathrm{~g}$; niacin $23.3 \mathrm{~g}$; retinol $2000 \mathrm{mg}$; cholecalciferol $25 \mathrm{mg}$; $\alpha$-tocopherol 23,000 mg IU.

At day 21, one bird from each cage was randomly selected and killed by cervical dislocation without previous starvation. Immediately, jejunum was removed and flushed with ice-cold saline. A $2 \mathrm{~cm}$ tissue section of mid jejunum was excised, frozen in liquid nitrogen, and stored at $-80^{\circ} \mathrm{C}$ for further analysis.

2.3. $m R N A$ Analysis. Total RNA was extracted from the jejunum samples (6 samples per treatment) using the RNeasy Midi Kit (Qiagen Inc., Valencia, CA) according to the manufacturer's protocol. Total RNA was quantified at 260/280 nm using the ND-1000 spectrophotometer (Nanodrop Technologies, Wilmington, DE) and stored at $-80^{\circ} \mathrm{C}$. The quality and integrity were also checked through agarose gel electrophoresis. The isolated RNA was subjected to two-step quantitative RT-PCR using the SYBR green assay with SYBR green PCR master mix (Applied Biosystems, Foster City, CA) using the ABI PRISM 7000 sequencing system (Applied Biosystems). Briefly, $10 \mu \mathrm{g}$ of total RNA was reverse-transcribed using Stratascript RT (Stratagene, La Jolla, CA) with oligo dT $(5 \mu \mathrm{g} / \mu \mathrm{L}$; IDT DNA, Coralville, IA) and random hexamers $(5 \mu \mathrm{g} / \mu \mathrm{L}$; IDT DNA). The cDNA $(6.25 \mathrm{ng})$ was used in $25 \mu \mathrm{L}$ PCR reaction with final concentration of $0.25 \mathrm{ng} / \mu \mathrm{L}$. Glyceraldehyde phosphate dehydrogenase (GAPDH) was used as the endogenous control gene and primers were designed using the Primer3 software [34, 35] (Table 2). PCR was performed under the following conditions: $50^{\circ} \mathrm{C}$ for $2 \mathrm{~min}, 95^{\circ} \mathrm{C}$ for $10 \mathrm{~min}$, and 40 cycles of $95^{\circ} \mathrm{C}$ for $15 \mathrm{~s}$ and $60^{\circ} \mathrm{C}$ for $1 \mathrm{~min}$. A dissociation step consisting of $95^{\circ} \mathrm{C}$ for $15 \mathrm{~s}, 60^{\circ} \mathrm{C}$ for $30 \mathrm{~s}$, and $95^{\circ} \mathrm{C}$ for $15 \mathrm{~s}$ was performed at the end of each PCR to 
TABle 2: Primer sequences $\left(5^{\prime} \rightarrow 3^{\prime}\right)$ used in real-time PCR.

\begin{tabular}{|c|c|c|c|c|}
\hline Name & Forward primer & Reverse primer & Product size (bp) & $\begin{array}{c}\text { Annealing } \\
\text { Temperature } \\
{ }^{\circ} \mathrm{C}\end{array}$ \\
\hline $\mathrm{SOD}^{\dagger}$ & AGGGGGTCATCCACTTCC & CCCATTTGTGTTGTCTCCAA & 122 & 62.1 \\
\hline CAT & GGGGAGCTGTTTACTGCAAG & TTTCCATTGGCTATGGCATT & 139 & 60 \\
\hline GST $\alpha$ & GCCTGACTTCAGTCCTTGGT & CCACCGAATTGACTCCATCT & 131 & 62.1 \\
\hline Hsp70 & AACCGCACCACACCCAGCTATG & CTGGGAGTCGTTGAAGTAAGCG & 359 & 65 \\
\hline IL2 & TGCAGTGTTACCTGGGAGAA & CTTGCATTCACTTCCGGTGT & 135 & 60.2 \\
\hline IL6 & GACTCGTCCGGAGAGGTTG & CGCACACGGTGAACTTCTT & 128 & 60.2 \\
\hline SGLT1 & TGTCTCTCTGGCAAGAACATGTC & GGGCAAGAGCTTCAGGTATCC & 229 & 60.2 \\
\hline SGLT5 & ATACCCAAGGTAATAGTCCCAAAC & TGGGTCCCTGAACAAATGAAA & 75 & 60 \\
\hline GLUT2 & CACACTATGGGCGCATGCT & ATTGTCCCTGGAGGTGTTGGTG & 116 & 60 \\
\hline GLUT5 & TTGCTGGCTTTGGGTTGTG & GGAGGTTGAGGGCCAAAGTC & 99 & 60 \\
\hline PepT1 & CCCCTGAGGAGGATCACTGTT & CAAAAGAGCAGCAGCAACGA & 205 & 60 \\
\hline EAAT3 & TGCTGCTTTGGATTCCAGTGT & AGCAATGACTGTAGTGCAGAAGTAATATATG & 79 & 60 \\
\hline GAPDH & GCCGTCCTCTCTGGCAAAG & TGTAAACCATGTAGTTCAGATCGATGA & 128 & 60 \\
\hline B-actin & ATGAAGCCCAGAGCAAAAGA & GGGGTGTTGAAGGTCTCAAA & 175 & 60 \\
\hline
\end{tabular}

${ }^{\dagger}$ SOD (superoxide dismutase); CAT (catalase); GST- $\alpha$ (3-glutathione S-transferase- $\alpha$ ); Hsp70 (heat shock protein); IL2 (interleukin 2); IL6 (interleukin 6); SGLT1 ( $\mathrm{Na}^{+}$-dependent glucose and galactose transporter); SGLT5 (glucose transporter); GLUT2 $\left(\mathrm{Na}^{+}\right.$-independent glucose, galactose and fructose transporter); GLUT5 ( $\mathrm{Na}^{+}$-independent fructose transporter); PepT1 (oligopeptide transporter); EAAT3 (excitatory amino acid transporter 3, $\mathrm{Na}^{+}, \mathrm{H}^{+}, \mathrm{K}^{+}$ dependent); GAPDH (glyceraldehyde phosphate dehydrogenase).

verify amplification of a single product. The specificity of the amplification product was further verified by electrophoresis on a $0.8 \%$ agarose gel and by DNA sequencing. A real-time PCR was conducted for each primer pair in which cDNA samples were substituted with distilled $\mathrm{H}_{2} \mathrm{O}$ to verify that exogenous DNA was not present. Additionally, $1 \mu \mathrm{g}$ of RNA isolated by the procedure described above was substituted for cDNA in a real time PCR reaction to confirm that no genomic DNA contaminants were present in the RNA samples. Both of these negative controls showed no amplification after 40 cycles. The cycle numbers at which amplified DNA samples exceeded a computer-generated fluorescence threshold level were normalized and compared with determined relative gene expression. Higher cycle number values indicated lower initial concentrations of cDNA and thus lower levels of mRNA expression. Each sample was run in duplicate, and averaged duplicates were used to assign cycle threshold (CT) values. The $\Delta \mathrm{CT}$ values were generated by subtracting experimental CT values from the CT values for GAPDH targets of each sample. The group with the highest mean $\Delta \mathrm{CT}$ value (lowest gene expression) per amplified gene target was set to 0 and the mean $\Delta \mathrm{CT}$ values of the other groups were set relative to this calibrator $(\Delta \Delta \mathrm{CT})$. The $\Delta \Delta \mathrm{CT}$ values were calculated as powers of $2\left(2^{-\Delta \Delta \mathrm{CT}}\right)$ to account for the exponential doubling of the PCR $[36,37]$.

2.4. Statistical Analysis. The mRNA expression data were analyzed by 2 -tailed $t$-test with unequal group variance using SAS statistical software [38]. The significance level was set at $P<0.05$.

\section{Results}

Exposure to $\mathrm{Pb}(200 \mathrm{mg} \mathrm{Pb} / \mathrm{kg}$ diet) significantly suppressed feed intake (FI) (Figure 1), body weight gain (BWG)

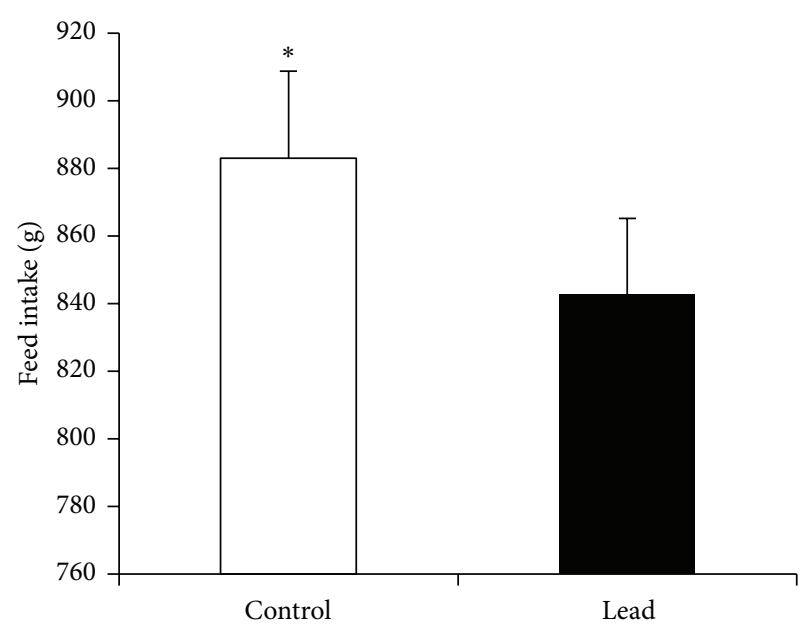

FIGURE 1: Effect of supplementation of $\mathrm{Pb}$ on feed intake in broiler chicken (1-21 days). Results are means of 6 replicates $(n=6)$. Error bar is standard deviation. ${ }^{*} P<0.05$.

(Figure 2), and feed efficiency (Figure 3). Higher standard deviation in $\mathrm{Pb}$-exposed birds may indicate the natural individual stress response variation.

The mRNA expressions of all studied sugar transporters except GLUT5 were significantly downregulated in $\mathrm{Pb}$ exposed chicks (Figure 4). The mRNA expression of GLUT5 was upregulated in chicks exposed to $\mathrm{Pb}$. A similar significant downregulation was observed in amino acid and peptide transporters mRNA expressions (Figure 5).

Exposure to $\mathrm{Pb}$ significantly increased the major antioxidant enzymes, namely, superoxide dismutase (SOD) and catalase (CAT) mRNA expression (Figure 6), while decreasing the mRNA level of 3-glutathione S-transferase- $\alpha$ (GST- $\alpha$ ) 


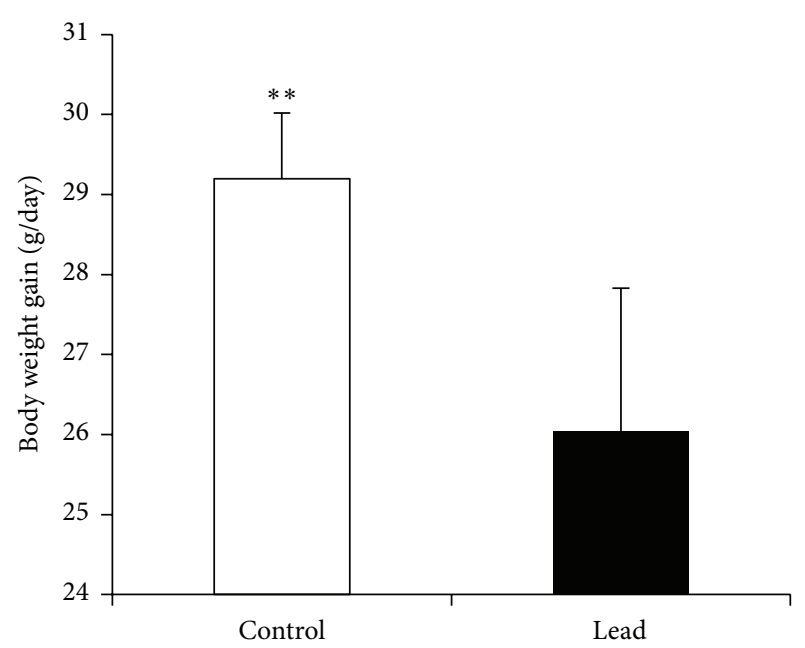

FIGURE 2: Effect of supplementation of $\mathrm{Pb}$ on body weight gain in broiler chicken. Results are means of 6 replicates $(n=6)$. Error bar is standard deviation. ${ }^{* *} P<0.01$.

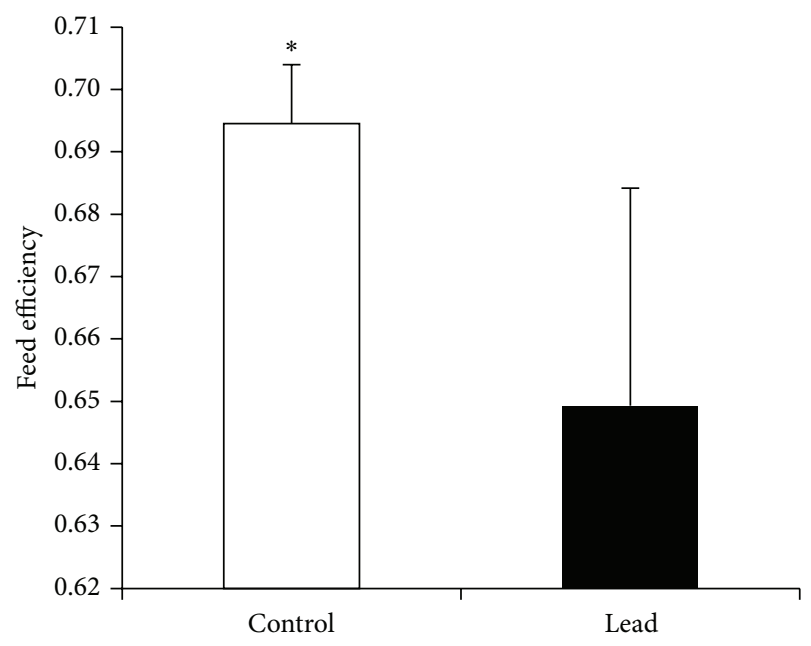

FIGURE 3: Effect of supplementation of $\mathrm{Pb}$ on feed efficiency in broiler chicken. Results are means of 6 replicates $(n=6)$. Error bar is standard deviation. ${ }^{*} P<0.05$.

(Figure 6). Regarding the heat shock protein 70 (Hsp70), our results showed that intestinal Hsp70 mRNA expression was significantly decreased in birds exposed to $\mathrm{Pb}$ (Figure 7).

\section{Discussion}

$\mathrm{Pb}$ has been shown to induce ROS generation, including hydroperoxides, singlet oxygen, and hydrogen peroxide $\left(\mathrm{H}_{2} \mathrm{O}_{2}\right)$ [39]. $\mathrm{Pb}$ has also been shown to both elevate and suppress levels of SOD, CAT, and glutathione peroxidase (GPx) $[40,41]$. Lower levels of exposure increase these enzymes, while higher exposure levels over long periods of time suppress them. In current study, as we used a moderate level of $\mathrm{Pb}$ exposure, $\mathrm{SOD}$ and CAT mRNA expression increased in response to $\mathrm{Pb}$-induced oxidative stress. This is in line with

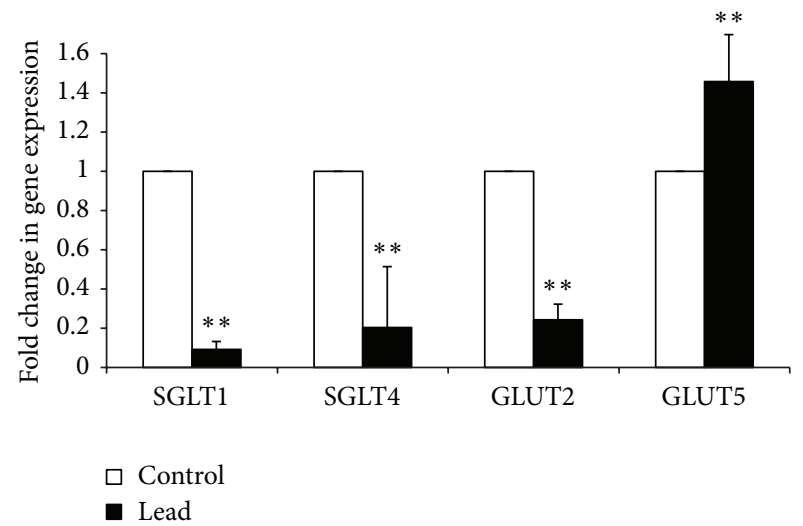

FIGURE 4: Effect of addition of $\mathrm{Pb}$ on relative mRNA abundance of SGLT1, SGLT4, GLUT2, and GLUT5 measured by real-time PCR in broiler chicken. Results are means of 6 replicates $(n=6)$. Error bar is standard deviation. ${ }^{* *} P<0.01$.

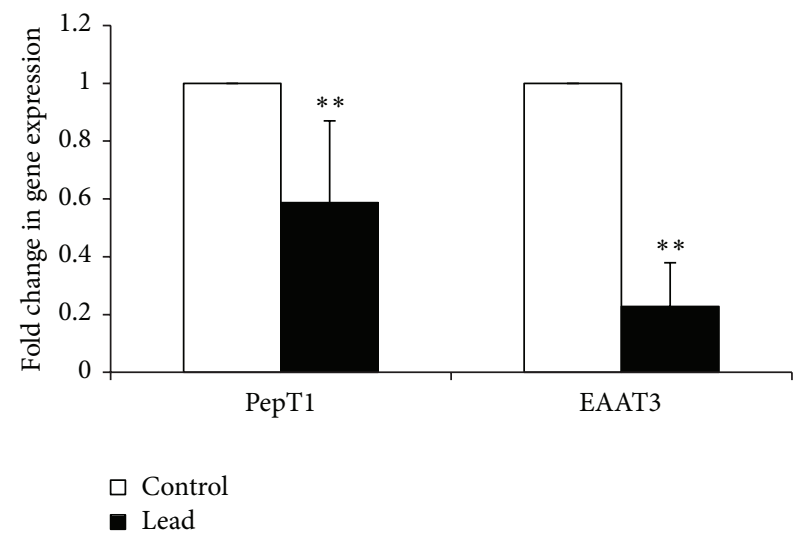

FIGURE 5: Effect of addition of $\mathrm{Pb}$ on relative mRNA abundance of PepT1 and EAAT3 measured by real-time PCR in broiler chicken. Results are means of 6 replicates $(n=6)$. Error bar is standard deviation. ${ }^{* *} P<0.01$.

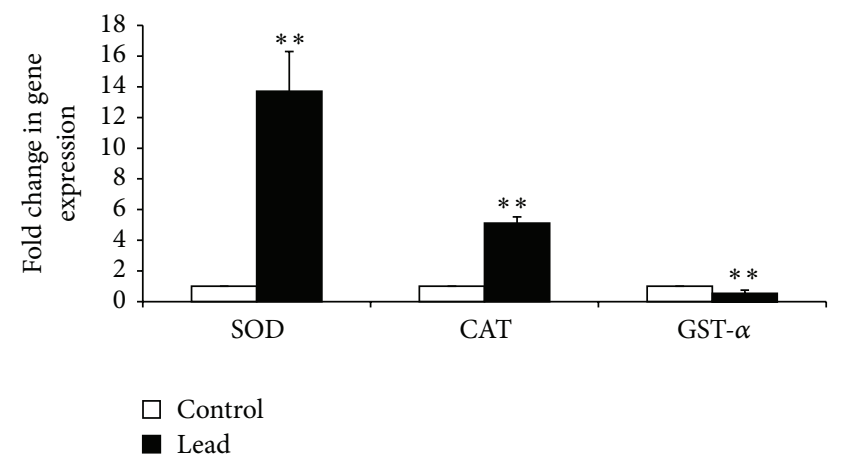

FIGURE 6: Effect of addition of $\mathrm{Pb}$ on relative mRNA abundance of antioxidant enzyme (SOD, CAT, and GST- $\alpha$ ) measured by real-time PCR in broiler chicken. Results are means of 6 replicates $(n=6)$. Error bar is standard deviation. ${ }^{* *} P<0.01$. 


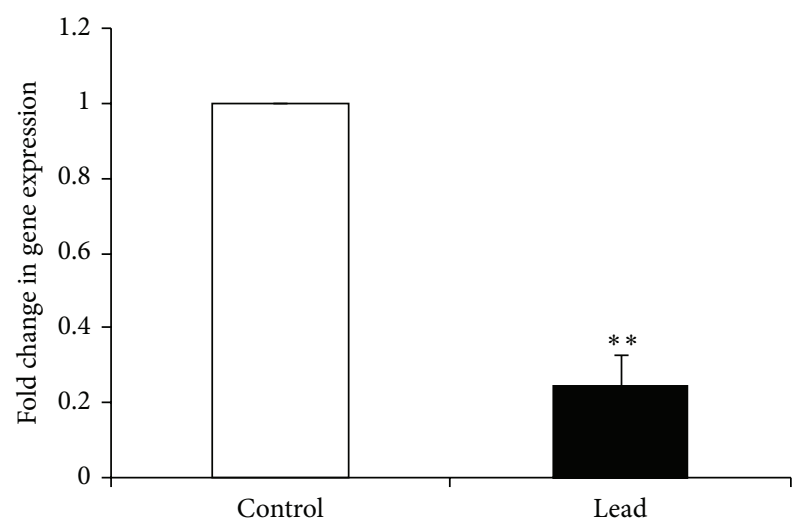

FIgURE 7: Effect of addition of $\mathrm{Pb}$ on relative mRNA abundance of Hsp70 measured by real-time PCR in broiler chicken. Results are means of 6 replicates $(n=6)$. Error bar is standard deviation. ${ }^{* *} P<$ 0.05 .

previous studies and is related to the $\mathrm{H}_{2} \mathrm{O}_{2}$ accumulation and following lipid peroxidation [10, 42-44]. However, we observed a likewise change for GST $\alpha$ expression. Maintenance of the cellular glutathione (GSH) in different cellular compartments is also critically regulated by GSTs $[45,46]$. The probable reason behind such observation is the positive correlation of GST $\alpha$ with Hsp70 expression. Studies by Volrn et al. [47] and Katsuki et al. [48] showed an interesting trend, in which cells under oxidative stress and tumors with high GSTs expression showed high Hsp70. In addition, immuneinhibition and immune-depletion studies showed that the Hsp70 chaperone is required for the efficient translation of GST $\alpha$ as well as its translocation to mitochondria $[46,49]$. Hsp70 binding to GST $\alpha$ prevents its rapid dimerization in the cytosol, making it import competent to mitochondria. In other words, lack of Hsp70 or its downregulation affects GST $\alpha$ expression. This phenomenon is interestingly observed in our study, whereby GST $\alpha$ and Hsp70 expression are suppressed alongside in birds under $\mathrm{Pb}$-induced oxidative stress. However, the question remains to be answered why $\mathrm{Hsp70}$ expression is reduced in $\mathrm{Pb}$-exposed birds? A possible explanation may be related to the upstream transcriptional regulation of Hsp70 expression via heat shock factor 1 (HSF1). Release of the HSF1 from the chaperone complex is ATP dependent and in turn is affected by general energy status of the cell $[50,51]$. Therefore, it has been suggested that a critical ATP level is required for activation of HSF1 [52]. Study by Chang et al. [52] indicated that a moderate decrease in intracellular ATP correlates with activation of HSF1 and a severe depletion in ATP correlates with an attenuation in HSF1 activation. Accordingly in our study, significant suppression of feed intake and the shortage of energy and ATP supply may attenuate HSF1 activation and consequently reduced Hsp70 expression.

Our results showed that addition of $200 \mathrm{mg} \mathrm{Pb} / \mathrm{kg}$ diet decreased feed intake and growth rate in broiler chicks. The decrease in feed intake and consequent growth rate suppression are difficult to explain with this study. However, recently, it has been speculated that $\mathrm{Pb}$-induced decrease in brain 5-hydroxytryptamine (5-HT; serotonin) level upregulates 5$\mathrm{HT}_{2 \mathrm{C}}$ receptor producing anorexia and anxiety in rats [53]. Furthermore, our result showed that $\mathrm{Pb}$-induced oxidative stress negatively affected the feed efficiency. While this effect is in part attributable to the $\mathrm{Pb}$-induced decrease in feed intake, it may also be directly related to associate metabolic and endocrine responses, as indicated by paired feeding studies [27, 54, 55]. Bolek and Persia [55] used a heat stress model in chicken and reported that approximately $54 \%$ of the reduced BWG was due to the effects of stress itself and the remaining BWG reduction was associated with reduced feed intake. It has been shown that chickens under heat stress have lower plasma thyroid hormones, weight, and length of the jejunum and higher corticosterone and apical SGLT1 expression than pair-fed groups [27]. At present, there is no report on the specific effect of $\mathrm{Pb}$-induced oxidative stress in a pair-fed experiment. However, with regard to the definition of stress response as the "general nonspecific increase in arousal" [56], it is likely to expect the same phenomenon in $\mathrm{Pb}$-induced oxidative stress. In this perspective, $\mathrm{Pb}$ stresslike response results in plasma corticosterone elevation [53, 57]. As a consequence, a vast range of glucocorticoids effects from decreasing feed intake to reducing intestinal absorptive surface area will take place [58]. In a physiological compensation feedback to maximize the sugar and amino acid uptake, nutrient transporters mRNA expression will be upregulated [27, 58-61]. In study by Garriga et al. [27], this response is reported to be triggered independently from the feed intake. They compared the SGLT1 activity and expression in heat stressed chickens with birds kept in thermoneutral condition and fed the same amount with heat stressed group. They observed that the activity and expression of SGLT-1 increased by $\sim 50 \%$ in the heat stressed chickens, without effects in the pair-fed thermoneutral group, indicating that other signals may be involved in the heat stress response. A probable candidate to mediate these effects is corticosterone. Dexamethasone induces expression of SGLT-1 in various species small intestine [58, 60, 61]. However, Douard et al. [60] reported that glucocorticoids had no or modest effect on SGLT1-1 and GLUT2 expression. In disagreement, our results showed that $\mathrm{Pb}$-exposure decreased the mRNA expression of SGLT1, SGLT4, GLUT2, PepT1, and EAAT3 in small intestine. Although there is no clear explanation for this observation, the discrepancies could be associated with the type of stressors. In Douard et al.'s [60] study, the stress condition was mimicked by glucocorticoid administration, while in our study we used $\mathrm{Pb}$-induced oxidative stress model. Moreover, a close look at our data reveals an interesting phenomenon which, by $\mathrm{Pb}$-induced oxidative stress, unlike the other sugar transporters, upregulated GLUT5 mRNA expression. This may be attributed to different functions of these sugar transporters. GLUT5 facilitates entry of fructose to epithelial cells through by facilitated diffusion. GLUT2 mediates the exit of monosaccharides from the enterocytes and SGLT1 and SGLT4 are responsible for the uptake of monosaccharide $[35,62,63]$. Pb exposure reduces entry of monosaccharides to enterocyte by downregulation of SGLT1 and SGLT4 and consequently reduces availability of GLUT2 substrate which in turn reduces mRNA expression of GLUT2. In response 
to this disruption and lack of energy in enterocyte level, the epithelial cells shift from energy consuming transporters (SGLT1 and SGLT4) to the one with no ATP requirement such as GLUT5 that is used to facilitate diffusion for fructose transportation. This speculation is supported by previous report of Douard et al. [60] where they showed that oxidative stress mimicked by dexamethasone injection dramatically increased expression of GLUT5 but not that of SGLT1 and GLUT2 in rat pups. Their investigation revealed six potential GR response elements in GLUT5 promoter regions 0-1250 bp upstream from the transcription start site, suggesting that dexamethasone could have a direct nuclear action. Therefore, it seems that GLUT5 regulation by glucocorticoids is specific and markedly different from SGLT1 and GLUT2.

In conclusion, our data showed that $\mathrm{Pb}$-induced oxidative stress adversely suppresses feed efficiency and growth performance in chicken. The proposed underlying mechanism for such phenomenon is downregulation of major nutrient transporters genes in small intestine.

\section{Abbreviations}

$\begin{array}{ll}\text { Pb: } & \text { Lead } \\ \text { PCR: } & \text { Polymerase chain reaction } \\ \text { SGLT1: } & \begin{array}{l}\text { Na+-dependent glucose and galactose } \\ \text { transporter }\end{array} \\ \text { SGLT5: } & \text { Glucose transporter } \\ \text { GLUT2: } & \text { Na+-independent glucose, galactose, and } \\ & \text { fructose transporter } \\ \text { GLUT5: } & \text { Na+-independent fructose transporter } \\ \text { PepT1: } & \text { Oligopeptide transporter } \\ \text { EAAT3: } & \text { Excitatory amino acid transporter } \\ \text { ALAD: } & \text { Delta-aminolevulinic acid dehydratase } \\ \text { GAPDH: } & \text { Glyceraldehyde phosphate dehydrogenase } \\ \text { FI: } & \text { Feed intake } \\ \text { BWG: } & \text { Body weight gain } \\ \text { Hsp70: } & \text { Heat shock protein } 70 \\ \text { 5-HT: } & \text { 5-Hydroxytryptamine } \\ \text { ROS: } & \text { Reactive oxygen species } \\ \text { GSH: } & \text { Glutathione } \\ \text { GST: } & \text { Glutathione S-transferases } \\ \text { HSF: } & \text { Heat shock factor } \\ \text { SOD: } & \text { Superoxide dismutase } \\ \text { CAT: } & \text { Catalase } \\ \text { Cd: } & \text { Cadmium. }\end{array}$

\section{Conflict of Interests}

The authors declare that they have no conflict of interests with any organization or entity in the subject matter discussed and publication of this paper.

\section{Acknowledgment}

This study was sponsored by the LRGS Fasa 1/2012 (Universiti Putra Malaysia) provided by the Ministry of Education Malaysia.

\section{References}

[1] Z. Erdogan, S. Erdogan, S. Celik, and A. Unlu, "Effects of ascorbic acid on cadmium-induced oxidative stress and performance of broilers," Biological Trace Element Research, vol. 104, no. 1, pp. 19-31, 2005.

[2] S. A. Mahesar, S. T. H. Sherazi, A. Niaz, M. I. Bhanger, S. uddin, and A. Rauf, "Simultaneous assessment of zinc, cadmium, lead and copper in poultry feeds by differential pulse anodic stripping voltammetry," Food and Chemical Toxicology, vol. 48, no. 8-9, pp. 2357-2360, 2010.

[3] S. K. Senapati, S. Dey, S. K. Dwivedi, and D. Swarup, "Effect of garlic (Allium sativum L.) extract on tissue lead level in rats," Journal of Ethnopharmacology, vol. 76, no. 3, pp. 229-232, 2001.

[4] W. Chang, J. Chen, Q.-Y. Wei, and X.-M. Chen, "Effects of Brn-3a protein and RNA expression in rat brain following lowlevel lead exposure during development on spatial learning and memory," Toxicology Letters, vol. 164, no. 1, pp. 63-70, 2006.

[5] R. K. Zalups and J. Koropatnick, Cellular and Molecular Biology of Metals, CRC, Boca Raton, Fla, USA, 2010.

[6] J. D. Hamilton and E. J. O'Flaherty, "Influence of lead on mineralization during bone growth," Fundamental and Applied Toxicology, vol. 26, no. 2, pp. 265-271, 1995.

[7] M. S. Maboeta, A. J. Reinecke, and S. A. Reinecke, "Effects of low levels of lead on growth and reproduction of the Asian Earthworm Perionyx excavatus (Oligochaeta)," Ecotoxicology and Environmental Safety, vol. 44, no. 3, pp. 236-240, 1999.

[8] A. Shabani and A. Rabbani, "Lead nitrate induced apoptosis in alveolar macrophages from rat lung," Toxicology, vol. 149, no. 23, pp. 109-114, 2000.

[9] N. Ercal, H. Gurer-Orhan, and N. Aykin-Burns, "Toxic metals and oxidative stress part I: mechanisms involved in metalinduced oxidative damage," Current Topics in Medicinal Chemistry, vol. 1, no. 6, pp. 529-539, 2001.

[10] M. Ahamed and M. K. J. Siddiqui, "Low level lead exposure and oxidative stress: current opinions," Clinica Chimica Acta, vol. 383, no. 1-2, pp. 57-64, 2007.

[11] J. Xu, L.-J. Lian, C. Wu, X.-F. Wang, W.-Y. Fu, and L.-H. Xu, "Lead induces oxidative stress, DNA damage and alteration of p53, Bax and Bcl-2 expressions in mice," Food and Chemical Toxicology, vol. 46, no. 5, pp. 1488-1494, 2008.

[12] A.-S. A. Newairy and H. M. Abdou, "Protective role of flax lignans against lead acetate induced oxidative damage and hyperlipidemia in rats," Food and Chemical Toxicology, vol. 47, no. 4, pp. 813-818, 2009.

[13] C. M. Liu, J. Q. Ma, and Y. Z. Sun, "Puerarin protects the rat liver against oxidative stress-mediated DNA damage and apoptosis induced by lead," Experimental and Toxicologic Pathology, vol. 64, no. 6, pp. 575-582, 2012.

[14] A. Bendich, "Physiological role of antioxidants in the immune system," Journal of Dairy Science, vol. 76, no. 9, pp. 2789-2794, 1993.

[15] R. G. Allen and M. Tresini, "Oxidative stress and gene regulation," Free Radical Biology and Medicine, vol. 28, no. 3, pp. 463499, 2000.

[16] A. B. Johnson and M. C. Barton, "Hypoxia-induced and stressspecific changes in chromatin structure and function," Mutation Research, vol. 618, no. 1-2, pp. 149-162, 2007.

[17] M. A. Valencia-Sanchez, J. Liu, G. J. Hannon, and R. Parker, "Control of translation and mRNA degradation by miRNAs and siRNAs," Genes and Development, vol. 20, no. 5, pp. 515-524, 2006. 
[18] J. D. Keene, "RNA regulons: coordination of post-transcriptional events," Nature Reviews Genetics, vol. 8, no. 7, pp. 533-543, 2007.

[19] K. Abdelmohsen, Y. Kuwano, H. H. Kim, and M. Gorospe, "Posttranscriptional gene regulation by RNA-binding proteins during oxidative stress: implications for cellular senescence," Biological Chemistry, vol. 389, no. 3, pp. 243-255, 2008.

[20] M. Roche, P. V. S. V. Neti, F. W. Kemp et al., "Radiation-induced reductions in transporter mRNA levels parallel reductions in intestinal sugar transport," American Journal of PhysiologyRegulatory Integrative and Comparative Physiology, vol. 298, no. 1, pp. R173-R182, 2010.

[21] B. L. Damron, C. F. Simpson, and R. H. Harms, "The effect of feeding various levels of lead on the performancef broilers," Poultry science, vol. 48, no. 4, pp. 1507-1509, 1969.

[22] J. Tomczok, H. Grzybek, W. Sliwa, and B. Panz, "Ultrastructural aspects of the small intestinal lead toxicology. Part I: surface ultrastructure of the small intestine mucosa in rats with lead acetate poisoning," Experimental Pathology, vol. 35, no. 1, pp. 49-55, 1988.

[23] F. W. Edens and J. D. Garlich, "Lead-induced egg production decrease in leghorn and japanese quail hens," Poultry Science, vol. 62, no. 9, pp. 1757-1763, 1983.

[24] R. I. Bakalli, G. M. Pesti, and W. L. Ragland, "The magnitude of lead toxicity in broiler chickens," Veterinary and Human Toxicology, vol. 37, no. 1, pp. 15-19, 1995.

[25] M. A. Mitchell and A. J. Carlisle, "The effects of chronic exposure to elevated environmental temperature on intestinal morphology and nutrient absorption in the domestic fowl (Gallus domesticus)," Comparative Biochemistry and Physiology Part A: Physiology, vol. 101, no. 1, pp. 137-142, 1992.

[26] A. Nasir, R. P. Moudgal, and N. B. Singh, "Involvement of corticosterone in food intake, food passage time and in vivo uptake of nutrients in the chicken (Gallus domesticus)," British Poultry Science, vol. 40, no. 4, pp. 517-522, 1999.

[27] C. Garriga, R. R. Hunter, C. Amat, J. M. Planas, M. A. Mitchell, and M. Moretó, "Heat stress increases apical glucose transport in the chicken jejunum," The American Journal of PhysiologyRegulatory Integrative and Comparative Physiology, vol. 290, no. 1, pp. R195-R201, 2006.

[28] X. F. Hu and Y. M. Guo, "Corticosterone administration alters small intestinal morphology and function of broiler chickens," Asian-Australasian Journal of Animal Sciences, vol. 21, no. 12, pp. 1773-1778, 2008.

[29] O. Gal-Garber, S. J. Mabjeesh, D. Sklan, and Z. Uni, "Partial sequence and expression of the gene for and activity of the sodium glucose transporter in the small intestine of fed, starved and refed chickens," Journal of Nutrition, vol. 130, no. 9, pp. 2174-2179, 2000.

[30] K. Naruhashi, Y. Sai, I. Tamai, N. Suzuki, and A. Tsuji, "PepT1 mRNA expression is induced by starvation and its level correlates with absorptive transport of cefadroxil longitudinally in the rat intestine," Pharmaceutical Research, vol. 19, no. 10, pp. 1417-1423, 2002.

[31] E. R. Gilbert, H. Li, D. A. Emmerson, K. E. Webb Jr., and E. A. Wong, "Dietary protein quality and feed restriction influence abundance of nutrient transporter mRNA in the small intestine of broiler chicks," Journal of Nutrition, vol. 138, no. 2, pp. 262271,2008 .

[32] I. Seven, T. Aksu, and P. Tatli Seven, "The effects of propolis and vitamin $\mathrm{C}$ supplemented feed on performance, nutrient utilization and carcass characteristics in broilers exposed to lead," Livestock Science, vol. 148, no. 1-2, pp. 10-15, 2012.

[33] National Research Council, Nutrient Requirements of Poultry, National Academy of Science, Washington, DC, USA, 9th edition, 1994.

[34] S. Rozen and H. Skaletsky, "Primer3 on the WWW for general users and for biologist programmers," Methods in Molecular Biology, vol. 132, pp. 365-386, 2000.

[35] E. R. Gilbert, H. Li, D. A. Emmerson, K. E. Webb Jr., and E. A. Wong, "Developmental regulation of nutrient transporter and enzyme mRNA abundance in the small intestine of broilers," Poultry Science, vol. 86, no. 8, pp. 1739-1753, 2007.

[36] K. J. Livak and T. D. Schmittgen, "Analysis of relative gene expression data using real-time quantitative PCR and the 2$\Delta \Delta$ CT method," Methods, vol. 25, no. 4, pp. 402-408, 2001.

[37] A. F. Soleimani, I. Zulkifli, A. R. Omar, and A. R. Raha, "Neonatal feed restriction modulates circulating levels of corticosterone and expression of glucocorticoid receptor and heat shock protein 70 in aged Japanese quail exposed to acute heat stress," Poultry Science, vol. 90, no. 7, pp. 1427-1434, 2011.

[38] SAS Institute, SAS/STAT Users Guide: Version 9.1, SAS Institute, North Carolina, NC, USA, 2001.

[39] R. Franco, R. Sánchez-Olea, E. M. Reyes-Reyes, and M. I. Panayiotidis, "Environmental toxicity, oxidative stress and apoptosis: Ménage à Trois," Mutation Research/Genetic Toxicology and Environmental Mutagenesis, vol. 674, no. 1-2, pp. 3-22, 2009.

[40] M. Chiba, A. Shinohara, K. Matsushita, H. Watanabe, and Y. Ihaba, "Indices of lead-exposure in blood and urine of leadexposed workers and concentrations of major and trace elements and activities of SOD, GSH-Px and catalase in their blood," The Tohoku Journal of Experimental Medicine, vol. 178, no. 1, pp. 49-62, 1996.

[41] L. Patrick, "Lead toxicity part II: the role of free radical damage and the use of antioxidants in the pathology and treatment of lead toxicity," Alternative Medicine Review, vol. 11, no. 2, pp. 114127, 2006.

[42] J. M. Mates and F. Sanchez-Jimenez, "Antioxidant enzymes and their implications in pathophysiologic processes," Frontiers in Bioscience, vol. 4, pp. 339-345, 1999.

[43] Ö. Yildirim and Z. Büyükbingöl, "Effect of cobalt on the oxidative status in heart and aorta of streptozotocin-induced diabetic rats," Cell Biochemistry and Function, vol. 21, no. 1, pp. 27-33, 2003.

[44] I. Seven, T. Aksu, and P. Tatli Seven, "The effects of propolis on biochemical parameters and activity of antioxidant enzymes in broilers exposed to lead-induced oxidative stress," AsianAustralasian Journal of Animal Sciences, vol. 23, no. 11, pp. 14821489, 2010.

[45] N. Allocati, L. Federici, M. Masulli, and C. Di Ilio, "Glutathione transferases in bacteria," FEBS Journal, vol. 276, no. 1, pp. 58-75, 2009.

[46] H. Raza, "Dual localization of glutathione $S$-transferase in the cytosol and mitochondria: implications in oxidative stress, toxicity and disease," FEBS Journal, vol. 278, no. 22, pp. 42434251, 2011.

[47] M. Volrn, R. Koomägi, J. Mattern, and G. Stammler, "Heat shock (hsp70) and resistance proteins in non-small cell lung carcinomas," Cancer Letters, vol. 95, no. 1-2, pp. 195-200, 1995.

[48] K. Katsuki, M. Fujimoto, X.-Y. Zhang et al., "Feeding induces expression of heat shock proteins that reduce oxidative stress," FEBS Letters, vol. 571, no. 1-3, pp. 187-191, 2004. 
[49] M. A. Robin, S. K. Prabu, H. Raza, H. K. Anandatheerthavarada, and N. G. Avadhani, "Phosphorylation enhances mitochondrial targeting of GSTA4-4 through increased affinity for binding to cytoplasmic Hsp70," The Journal of Biological Chemistry, vol. 278, no. 21, pp. 18960-18970, 2003.

[50] S. K. Van Why, S. Kim, J. Geibel, F. A. Seebach, M. Kashgarian, and N. J. Siegel, "Thresholds for cellular disruption and activation of the stress response in renal epithelia," American Journal of Physiology: Renal Physiology, vol. 277, no. 2, pp. F227-F234, 1999.

[51] S. Inouye, K. Katsuki, H. Izu et al., "Activation of heat shock genes is not necessary for protection by heat shock transcription factor 1 against cell death due to a single exposure to high temperatures," Molecular \& Cellular Biology, vol. 23, no. 16, pp. 5882-5895, 2003.

[52] J. Chang, A. A. Knowlton, F. Xu, and J. S. Wasser, "Activation of the heat shock response: relationship to energy metabolites. A 31P NMR study in rat hearts," American Journal of Physiology: Heart and Circulatory Physiology, vol. 280, no. 1, pp. H426H433, 2001.

[53] S. Haider, S. Saleem, S. Tabassum et al., "Alteration in plasma corticosterone levels following long term oral administration of lead produces depression like symptoms in rats," Metabolic Brain Disease, vol. 28, no. 1, pp. 85-92, 2013.

[54] H. Lin, E. Decuypere, and J. Buyse, "Oxidative stress induced by corticosterone administration in broiler chickens (Gallus gallus domesticus): 1. Chronic exposure," Comparative Biochemistry and Physiology Part B: Biochemistry and Molecular Biology, vol. 139, no. 4, pp. 737-744, 2004.

[55] K. J. Bolek and M. E. Persia, "The effect of chick methionine status on broiler performance and physiological response to acute and chronic heat stress," Animal Industry Report. Iowa State University, 2013.

[56] S. Levine and H. Ursin, "What is stress?" in Stress: Neurobiology and Neuroendocrinology, M. R. Brown, G. F. Koob, and C. Rivier, Eds., pp. 3-21, Marcel Dekker, New York, NY, USA, 1991.

[57] D. A. Cory-Slechta, M. B. Virgolini, M. Thiruchelvam, D. D. Weston, and M. R. Bauter, "Maternal stress modulates the effects of developmental lead exposure," Environmental Health Perspectives, vol. 112, no. 6, pp. 717-730, 2004.

[58] X. F. Hu, Y. M. Guo, B. Y. Huang et al., "The effect of glucagonlike peptide 2 injection on performance, small intestinal morphology, and nutrient transporter expression of stressed broiler chickens," Poultry Science, vol. 89, no. 9, pp. 1967-1974, 2010.

[59] T. Ihara, T. Tsujikawa, Y. Fujiyama, and T. Bamba, "Regulation of PepT1 peptide transporter expression in the rat small intestine under malnourished conditions," Digestion, vol. 61, no. 1, pp. 59-67, 2000.

[60] V. Douard, H.-I. Choi, S. Elshenawy, D. Lagunoff, and R. P. Ferraris, "Developmental reprogramming of rat GLUT5 requires glucocorticoid receptor translocation to the nucleus," The Journal of Physiology, vol. 586, no. 15, pp. 3657-3673, 2008.

[61] S. D. Reichardt, M. Föller, R. Rexhepaj et al., "Glucocorticoids enhance intestinal glucose uptake via the dimerized glucocorticoid receptor in enterocytes," Endocrinology, vol. 153, no. 4, pp. 1783-1794, 2012.

[62] M. Uldry and B. Thorens, "The SLC2 family of facilitated hexose and polyol transporters," Pflugers Archiv European Journal of Physiology, vol. 447, no. 5, pp. 480-489, 2004.

[63] E. M. Wright and E. Turk, "The sodium/glucose cotransport family SLC5," Pflügers Archiv, vol. 447, no. 5, pp. 510-518, 2004. 

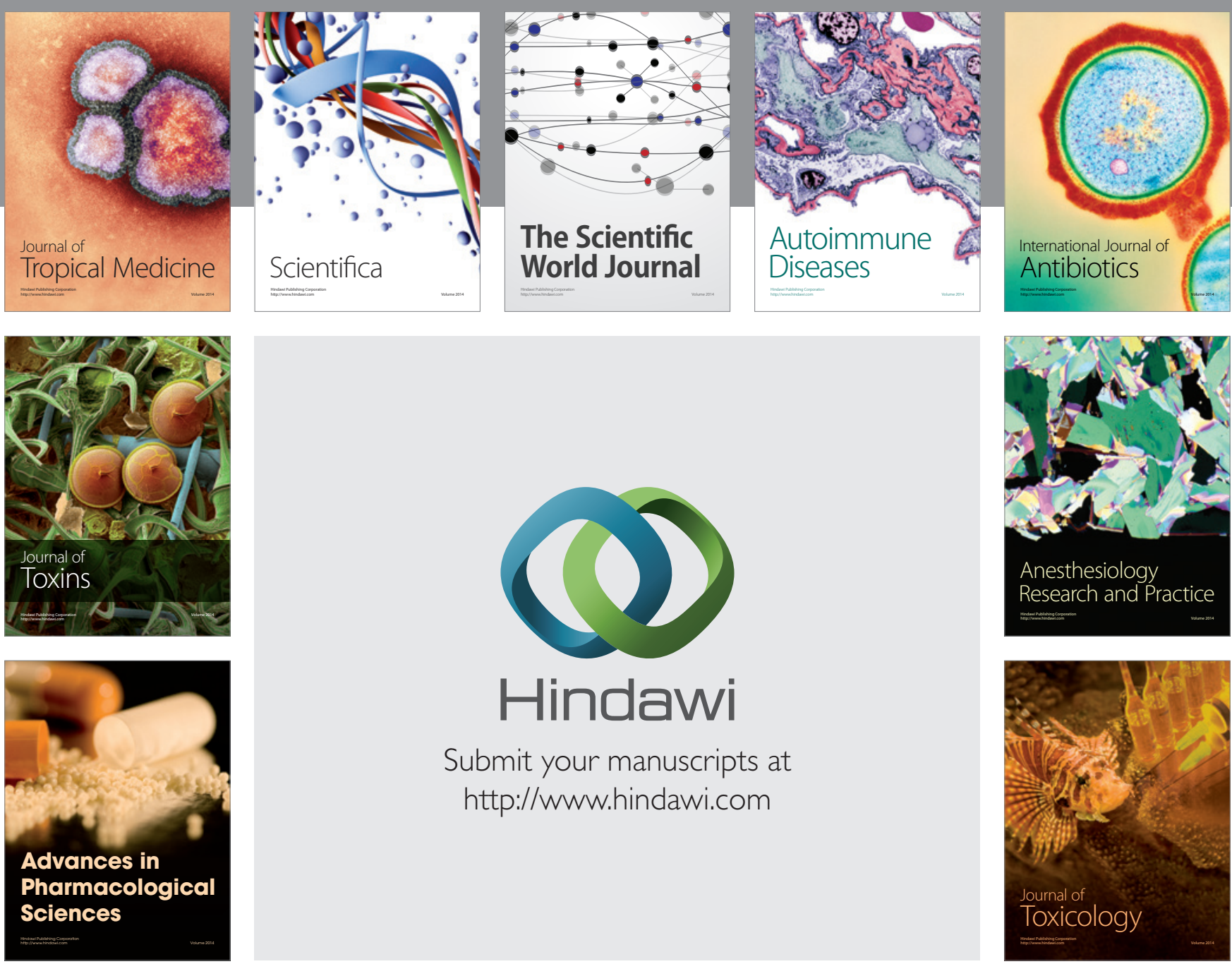

\section{Hindawi}

Submit your manuscripts at

http://www.hindawi.com
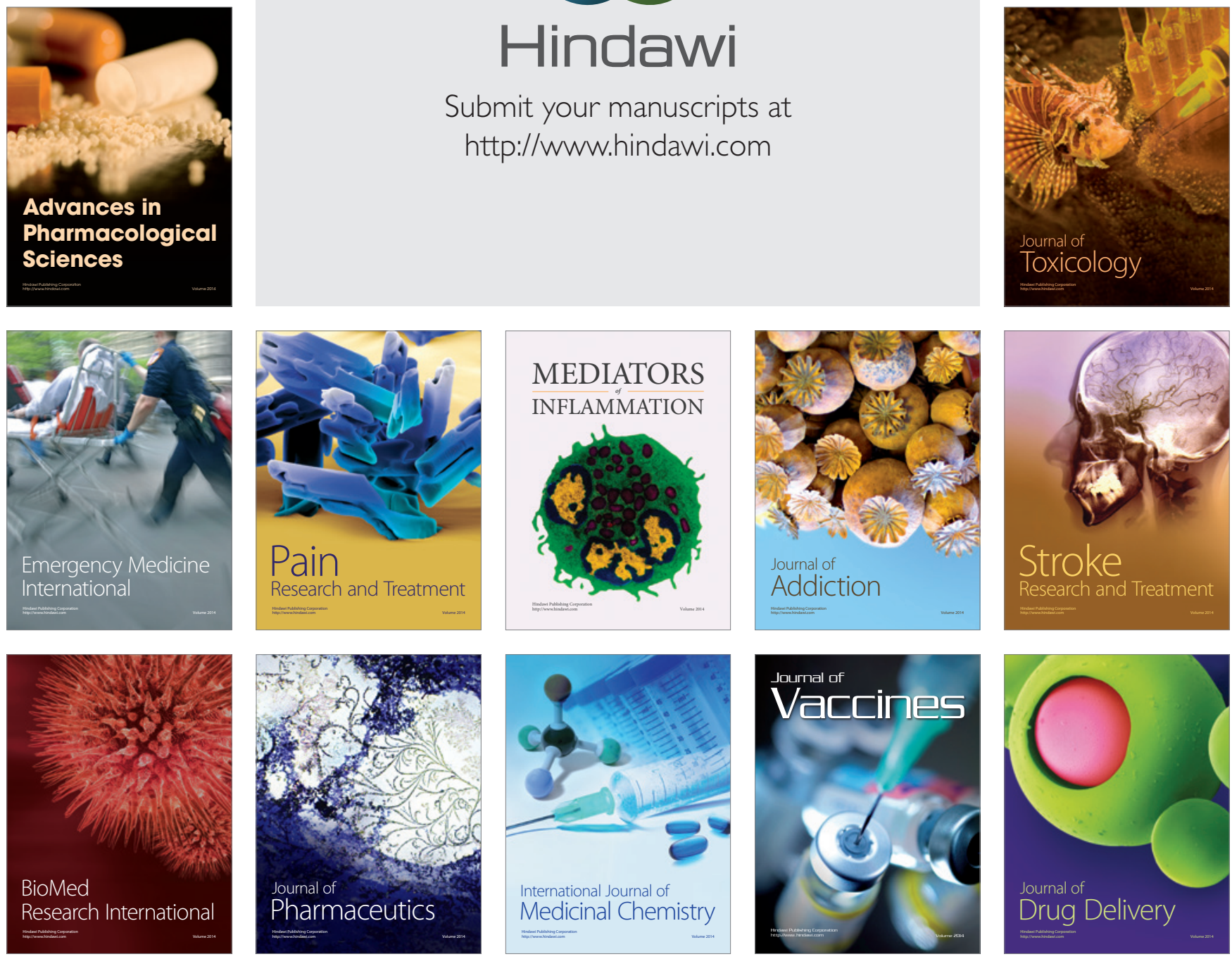